\title{
PEMBENTUKAN KARAKTER RELIGIUS SISWA MELALUI PENDIDIKAN HUMANIS (Studi Kasus di SMK NU 2 Kedungpring Kabupaten Lamongan)
}

\author{
Yoyok Amirudin \\ Universitas Islam Malang \\ yoyok.amirudin@unisma.ac.id
}

\section{Article History:}

Received : 06-06-2019

Revised : 15- 08-2019

Accepted : 08-09-2019

\begin{abstract}
This study discusses the formation of students' religious character through humanist education at SMK NU 2 Kedungpring, Lamongan Regency. This research is a case study research using a qualitative approach. Meanwhile, seen from the data presentation technique in this study using descriptive methods. The method used in this research with data collection techniques is the technique of observation, interviews, and documentation. While the data analysis technique used is descriptive qualitative analysis techniques. The results of this study indicate that the teacher acts as a trendsetter for the development of religious character through habituation, learning and interaction that emphasizes Islamic values. The factors that influence the formation of religious character through humanist education include the commitment of teachers who are not simultaneously in the development of religious character, besides that the lack of the number of religious teachers and the limited number of school facilities and infrastructure also affects the character building of humanist-religious students.
\end{abstract}

Keywords: character building, humanist education, religious student

\section{Pendahuluan}

Pendidikan merupakan upaya sekolah dalam menjembatani dan mempersiapkan siswa untuk memajukan pola pikir yang berwawasan luas dan hidupnya yang berkualitas intelektualnya, emosionalnya, spiritualnya dan membimbingnya menjadi orang yang bermanfaat hidupnya nanti kelak di masyarakat. Maka dari itu, rangkaian tindakan dalam mendidik yang benar adalah melepaskan jiwa peserta didik dari berbagai belenggu, ancaman, dan pemerasan. Dengan demikian, menjadikan peserta didik sebagai manusia yang mempunyai keyakinan dan ketaatan kepada Allah merupakan ukuran atau dasar penilaian dalam proses pengubahan sikap dan perilaku seseorang. Artinya, pendidikan yang bersifat keagamaan dan membebaskan jiwa peserta didik sangat diperlukan sebagai pondasi untuk peserta didik. Untuk membentuk itu semua maka harus di butuhkan pendidikan yang bersifat humanis yakni melihat bahwa 
manusia adalah siswa yang memiliki karakteristik juga potensi yang harus dikembangkan.

Bagi pandangan masyarakat, banyaknya kasus tawuran pelajar, minuman keras, narkoba, pencurian, seks bebas, korupsi, makar, adu domba, intimidasi, dan segala kekerasan yang dilakukan pelajar dan pejabat itu mengindikasikan bahwa pendidikan nilai-nilai kemanusiaan belum maksimal diaplikasikannya. Pendidikan humanis saja yang mengedepankan harkat dan martabat manusia masih harus menghadapi persoalan, bukan dalam aspek prosesnya namun juga perwujudan hasil dari pendidikan itu sendiri. Berbicara nilai-nilai kemanusiaan, tentunya tidak lepas dari karakter dan kepribadian manusia. Manusia adalah makhluk dengan berbagai karakter. Ada yang berkarakter baik, dan ada juga yang berkarakter buruk. Makna pada karakter mengandung maksud sebagai kepribadian yang dimiliki manusia atau juga bisa dimaknai sebagai perbuatan manusia yang selalu dilakukan berulang-ulang. ${ }^{1}$ Oleh karena itu, karakter tidak datang dengan sendirinya, karena karakter bukan bawaan sejak lahir. Karakter tidak bisa diwariskan melalui keturunan, akan tetapi karakter harus dibangun dan dibentuk.

Dengan demikian, agama sangat berpengaruh penting dalam pembentukan karakter peserta didik. Faktor agama dapat membentuk peserta didik memiliki karakter religius, sebab karakter tersebut memiliki nilai-nilai kebenaran yang berasal dari keyakinannya masing-masing. Hal ini sejalan dengan pemikiran Thomas Lickona menegaskan agar memiliki tiga unsur karakter yang berguna dan menentukan dalam pembentukan karakter peserta didik, yakni mengerti dan memahami tentang makna moral, merasakan tentang esensi dari makna moral, dan mewujudkan pemahaman dengan sikap dan berperilaku yang bermoral. ${ }^{2}$

Pada penelitian ini peneliti menggunakan metodelogi kualitatif sebagai prosedur peneletian yang menghasilkan data deskriptif berupa kata-kata tertulis atau lisan dari orang-orang dan perilaku yang dapat diamati. ${ }^{3}$ Penelitian kualitatif mempunyai dua tujuan utama yaitu: pertama, menggambarkan dan mengungkapkan, dan kedua menggambarkan dan menjelaskan. Kebanyakan penelitian kualitatif bersifat deskriptif dan eksplanatori. Beberapa penelitian memberikan deskriptrif tentang situasi yang kompleks, dan arah bagi penelitian selanjutnya. Penelitian lain memberikan eksplanasi (kejelasan) tentang hubungan antara peristiwa dengan makna terutama menurut presepsi partisipan. ${ }^{4}$ Jenis dan pendekatan penelitian yang digunakan adalah jenis penelitian kualitatif, karena pada penelitian ini memfokuskan pengamatan dalam hal-hal yang terjadi dilapangan. Hal ini bertujan agar dapat meberikan penjelasan dan suatu gambaran secara utuh dan terorganisasi dengan baik tentang komponen-komponen tertentu sehingga dapat memberikan kevalidan dari hasil penelitian. Sedangkan pendekatan dalam penelitian ini menggunakan pendekatan deskriptif yakni data yang

1 Abdul Majid dan Dian Andayani, Pedidikan Karakter Prespektif islam (Bandung: PT Rosdakarya, 2013), 11.

2 Thomas Lickona, Educating For Character: How Our School Can Teach Respect And Responsibility (New York: Bantam Books, 1991), 51.

${ }^{3}$ Lexy J. Moleong, Metode Penelitian Kualitatif (Bandung: PT. Remaja Rosda Karya, 2006), 4.

${ }^{4}$ Nana Syaodih Sukmadinata, Metode Penelitian Pendidikan (Bandung: Remaja Rosda Karya, 2008), 60. 
dikumpulkan oleh peneliti adalah berupa kata-kata, dan gambar. Adapun data yang dimaksud dari hasil wawancara, catatan lapangan, foto, videotape, dokumentasi, pribadi, catatan atau memo, dan dokumen resmi lainnya. ${ }^{5}$

Subyek penelitian adalah sumber untuk mendapatkan data subyek penelitian digunakan untuk memperoleh informasi yang diperlukan. ${ }^{6}$ Berkenaan dengan hal itu maka peneliti merasa tertarik untuk meneliti mengenai pembentukan karakter religus melalui pendidikan humanis pada peserta didik. Untuk memfokuskan proses penenlitian, maka peneliti memilih SMK NU 2 Kedungpring sebagai tempat penelitian.

Sumber dan jenis data: adapun sumber dan jenis data di bagi menjadi 2 yaitu: 1 ) data primer yaitu data yang bersifat pokok adalah bahan utama yang terdapat di lapangan. Sumber data primer diperoleh dari hasil wawancara dan hasil observasi dilapangan. 2) data sekunder yaitu data yang bersifat pelengkap atau tambahan yang relevan pada penelitian dan sebagian penunjang dari data utama.

Teknik pengumpulan data: adapun cara yang digunakan dalam penelitian meliputi: 1) Interview/wawancara: rangkaian tindakan dalam memperoleh penjelasan data secara tatap muka antara penanya dengan informan. Adapun informan yang dimintai keterangan dalam penelitian ini meliputi: kepala sekolah, guru kelas, Siswasiswi di SMK NU 2 Kedungpring. 2) Dokumentasi: menghimpun data dari berbagai arsip baik yang sudah lama maupun yang baru, misal foto, dan berbagai media yang berhubungan dengan judul yang diteliti. 3) Observasi: meninjau secara cermat pada peristiwa yang terjadi di lapangan, peneliti melakukan observasi untuk mengetahui lebih dekat obyek yang diteliti meliputi: letak geografis di SMK NU 2 Kedungpring, sarana prasarana dan fasilitas fisik lainnya. ${ }^{7}$

Teknik analisis data: Peneliti menelaah bahan secara keseluruhan menggunakan beberapa cara yaitu: Reduksi data adalah merangkum, memilih hal-hal yang pokok,.8 Penyajian data: penyajian data dilakukan dalam bentuk tabel, grafik, phie chard, pictogram dan sejenisnya. Melalui penyajian data tersebut, maka data terorganisasikan, tersusun dalam pola hubungan, sehingga akan semakin mudah difahami. ${ }^{9}$ Menarik kesimpulan: mengambil data inti dari pembentukan karakter religius siswa melalui Pendidikan humanis di SMK NU 2 Kedungpring untuk disimpulkan secara singkat, padat dan jelas. ${ }^{10}$

Teknik keabsahan data meliputi: Kredibilitas adalah: suatu hal berpotensi terdapat kerancuan data atau bisa jadi sebagai peneliti masih memiliki ego sepihak untuk menentukan hasil observasi di lapangan. Transferbilitas adalah: menguraikan data secara rinci, agar para pembaca dapat memahami temuan-temuan hasil penelitian di lapangan. Konfirmabilitas juga digunakan untuk mengecek data dengan

\footnotetext{
${ }^{5}$ Lexy J, Moleong, Metode Penelitian Kualitatif (Bandung: PT. Remaja Rosda Karya, 2006), 11.

${ }^{6}$ Ibid, 158.

${ }^{7}$ Bungin Bungin, Penelitian Kualitatif, (Jakarta: Prenada Media Group, 2007), 115.

${ }^{8}$ Ibid, 337,.

${ }^{9}$ Ibid, 248,

${ }^{10}$ Matthew B. Miles and A. Michele Hubberman, Qualitative Data Analysis: An Expanded Sourcebook (London: SAGE Peblication, 1994), 11.
} 
mengkonfirmasikan temuan data dengan para informan. Sehingga, terdapat penegasan dalam melakukan pembenaran secara ilmiah. ${ }^{11}$

\section{Tinjuan Konseptual Karakter Religius}

Arti yang mudah untuk di pahami dalam memaknai Pendidikan Karakter adalah usaha untuk membina dan memajukan mutu siswa dengan sistem yang berkesinambungan yang bersumber pada ajaran agama, kebudayaan yang beradab, dan pandangan hidup yang diwujudkan oleh siswa pada sikap dan perilaku sebagai mana mestinya ketika dilingkungan rumah, sekolah, maupun dalam berinteraksi dengan masyarakat setiap hari. ${ }^{12}$ Sedangkan menurut Mohammad Mustari berpendapat bahwa Religius adalah sifat keagamaan yang bersumber pada ajaran agama dan berkaitan kuat dengan tuhan. Hal ini menandakan bahwa pola hidup, pola ucapan, dan pola perbuatan setiap manusia yang digunakan dalam kehidupannya senantiasa bersendikan pada petunjuk dari tuhan dan ajaran agama. ${ }^{13}$

Agama yang dimaksud ada pembahasan ini adalah agama islam. Islam memiliki makna pasrah, menyerahkan sepenuh diri. Islam adalah nama bagi suatu agama yang berasal dari Allah Swt. Kata Islam tidak mempunyai hubungan dengan orang tertentu atau golongan manusia atau negeri tertentu. Hikmah tertinggi dari perbedaan Islam yang paling menonjol adalah bahwa Islam agama wahyu dari Allah Swt. Menurut Muhammad Fathurrohman Pendidikan karakter religius dapat dimaknai sebagai usaha dalam memberikan arahan untuk peserta didik supaya merasakn dan menjalani isi dari ajaran-ajaran agama untuk diterapkan secara keseluruhan dalam kehidupannya. ${ }^{14}$ Maka pembinaan karakter manusia dalam memiliki pandangan hidup, ucapan, dan berperilaku yang senantiasa bersumber pada ajaran agama. Sehingga, manusia yang berkarakter religius dalam kehidupan pribadinya, dan bermasyarakat, mereka bertujuan untuk meneguhkan keyakinannya dan kepatuhannya kepada Allah Swt. Oleh sebab itu, manusia yang sudah memiliki karakter religius sepatutnya dijadikan sebagai teladan yang baik.

Dengan demikian dapat disimpulkan pendidikan karakter religius adalah upaya pengajaran dan pelatihan yang direncanakan secara berkesinambungan untuk menghasilkan sifat kebaikan yang bernilai keagamaan seperti ibadah, memiliki akhlak, kedisiplinan, dan keteladanan bersumber dari agama yang dianutnya. Sehingga pembinaan religius tersebut dapat menjadikannya sebagai seseorang yang berkarakter, dan menjadi manusia seutuhnya yang berkualitas lahir dan batinnya, baik dari segi pribadinya yang akan bermanfaan bagi dirinya sendiri, masyarakat dan lingkungan. Maka dalam konteks Pendidikan karakter religius sendiri, dapat diartikan utuh jika seseorang dapat berfikir, bersikap, dan bertindak sesuai sumber-sumber agama islam

${ }^{11}$ Lincoln and Guba, Effective Evaluation, Improving The Usefullness Of Evaluation Result Hrough Responsive And Naturalistic Approaches (San Fransisco: California, 1981), 31.

${ }^{12}$ Aan Hasanah, Pendidikan Karakter Prespektif Islam, (Bandung: Insan Komunikasi,2012), 5.

${ }^{13}$ Mohammad Mustari, Nilai Karakter: Refleksi untuk Pendidikan, (Jakarta: PT Raja Grafindo Persada, 2014), 1.

${ }^{14}$ Muhammad Fathurrohman, Budaya Religius Dalam Peningkatan Mutu Pendidikan: Tujuan Teoritik dan Praktik Kontekstualisasi di Sekolah, (Yogyakarta: Kalimedia, 2015), 75. 
dalam melakukannya tidak perlu berfikir Panjang serta tidak dapat terpengaruh dengan keadaan, waktu, maupun situasi yang ada.

Dimensi-dimensi karakter religius yaitu menerapkan ajaran agama dapat dipraktekkan dengan beraneka ragam bentuknya dalam berinteraksi dengan manusia. Oleh sebab itu, ketika manusia menjalankan ajaran agama secara keseluruhan, maka manusia tersebut akan mengalami dan memasuki beragam jenis ruang dimensi pada agama. Dimensi karakter religius dibagi menjadi 4 yaitu:

1. Dimensi keyakinan atau keimanan (belief) yaitu: bentuk usaha dalam membina dan membentuk keimanan anak pada sang maha kuasa yakni Allah. Dalam dimensi ini merupakan proses awal yang dialami seorang anak dalam menjalankan kewajibannya sebagai hamba Allah dan menerima segala bentuk takdir yang telah digariskan pada dirinya tanpa mengeluh dan putus asa.

2. Dimensi peribadatan atau praktik agama (practical) yaitu: mencermikan perwujudan hasil yang berupa pelaksanaan ibadah secara nyata dari dimensi pertama yang menjadi landasan tauhid. Seluruh kegiatan dalam beribadah hanya bertujuan untuk mengukuhkan hati dalam menjalin hubungan dengan Allah. Beribadah merupakan unsur yang penting dalam menjaga kondisi keamanan manusia, agar tetap stabil dan tidak goyah ketika mendapatkan ujian kehidupan.

3. Dimensi pengalaman dan konsekuensi (the consequential dimension/ religious effect) yaitu: tindakan nyata dari penjelasan beberapa dimensi diatas. Pelaksanaan dalam beribadah adalah membimbing seluruh perbuatan manusia untuk selalu bersandar pada Allah secara lahir dan batin.

4. Dimensi pengetahuan agama (intellectual) yaitu: pada dimensi ini berisi tentang teori dan gagasan dalam ajaran agama, mulai dari segi keimanan, unsur-unsur yang menata kehidupan manusia, tata cara dalam melakukan ibadah dan aturan-aturan menjadi manusia yang religius juga memiliki keimanan yang tanguh pada ajaran agamanya. Pada dimensi ini menjadi penunjang yang akan membawa seseorang dalam terbinanya kerakter religius. ${ }^{15}$

Nilai-nilai karakter religius yakni: dasar dari terbentuknya sifat religius dalam Pendidikan adalah bertumpu pada ajaran-ajaran agama. Arah dari orientasi pembentukan sifat religius melalui Pendidikan adalah dapat berguna bagi siswa dan siswa mampu untuk menghayati makna yang sesungguhnya yang terdapat pada ajaranajaran agama. Nilai-nilai religius yang berlangsung dalam kehidupan manusia dikategorikan menjadi dua bentuk yaitu:

1. Nilai ketuhanan adalah: ukuran kebenaran yang berasal dari tuhan melalui ajaran agama. Keimanan adalah bagian utama dalam beragama. Upaya pendidikan dalam memupuk ajaran agama adalah pengajaran yang terpenting. Dasar yang paling pokok dalam nilai ketuhanan meliputi: a) iman: sikap keteguhan hati dan ketetapan batin yang dipenuhi keyakinan yang kuat terhadap allah. b) islam: sikap berserah diri kepada Allah secara lahir dan batin. c) ihsan: sikap yang membimbing manusia

${ }^{15}$ Djamaludin Ancok dan Fuad Nasori Suroso, Psikologi Islam (Yogyakarta: Pustaka Pelajar, 2005), 7678. 
untuk dapat merasakan bahwa Allah selamanya menemani kita. Segala niat perbuatan buruk yang dijalani menjadi gagal dilakukan akibat mampu merasakan bahwa Allah itu ada. d) taqwa: sikap melaksanakan yang telah diperintahkan oleh Allah dan mentaati segala sesuatu yang sudah dilarang oleh Allah. e) ikhlas: sikap ketulusan dalam melakukan perbuatan, tidak menerima pamrih dan tidak mengharapkan sebuah imbalan dari sesama ciptaan Allah. Semuanya dilakukan murni hanya untuk Allah. f) tawakkal: sikap berserah diri kepada Allah setelah melakukan ikhtiar. Sebuah harapan dari hasil yang telah diikhtiarkan sepenuhnya diserahkan kepada Allah. g) syukur: sikap yang tidak pernah mengeluh atas segala yang telah diberikan oleh Allah. Baik berupa kenikmatan hidup maupun kesengsaraan dalam hidup. Menjalani berbagai macam dinamika kehidupan dengan penuh rasa maksiat. h) sabar: sikap menahan hawa nafsu dan amarah yang menyadaari akan jati dirinya dihadapan Allah.

2. Nilai kemanusiaan adalah: ajaran yang berkaitan dengan ciptaan Allah dengan upaya melaui berinteraksi dalam kehidupan sehari-hari. Nilai kemanusiaan meliputi: a) silaturrahmi: saling menjalin hubungan baik antar manusia. b) persaudaraan: giat dalam menjaga hubungan saudara. c) tidak membeda-bedakan: semuanya dianggap sama, dengan tidak memandang dan membedakan ras, status, dan jabatan. d) keseimbangan ilmu pengetahuan: sebagai manusia hurus menyeimbangkan dalam mencari ilmu agama dan ilmu umum. e) berprasangka baik: berfikir positif dalam menilai sesama manusia. Selalu menilai orang dengan pandangan kebaikan yang selalu tampak pada orang yang dinilai. f) kerendahan hati: menjauhi sifat sombong dan angkuh. g) menepati janji: tidak mengingkari apa yang sudah disepakati. h) dapat dipercaya: sikap bertanggung jawab atas perbuatan dan lisan yang telah dilakukan. i) menjaga harga diri: sikap kesadaran atas beberapa basar nilai yang diberikan pada diri sendiri. j) sederhana: sikap yang dapat menggunakan harta dengan sewajarnya. k) ringan tangan: sikap yang dapat menggunakan harta dengan sewajarnya.

Metode pembentukan karakter religius dapat menggunakan dengan cara: a) teladan yaitu: upaya pengubahan perilaku, pola pikir, dan cara bertutur kata dapat dilakukan dengan memberikan contoh yang baik pada siswa. b) membangun budaya sekolah berbasis religius yaitu: Rangkaian kegiatan yang sangat perbengaruh besar dalam membentuk budaya disekolahan keterlibatannya semua pihak sekolah secara keseluruhan supaya untuk berkomitmen dan memajukan perkembangan sekolah dengan harus mengutamakan tujuannya dengan memusatkan perhatiannya pada upaya memupuk dan membina nilai religius, membuat peraturan, dan pembiasaan yang nantinya menjadi karakter siswa secara permanen. c) Pembelajaran yaitu: Kegiatan sekolah dalam proses upaya pengajaran dan pelatihan dalam membina karakter religius dapat dilaksanakan oleh pendidik dengan berbagai strategi. Rangakian aktivitas di kelas yang dilakukan saat pembelajaran dan nilai religius dapat dicantumkannya. ${ }^{16}$ d) Penguatan yaitu: Dalam memperkuat karakter siswa tidak sebatas di laksanakan dalam

${ }^{16}$ Ngainun Naim, Character Building: Optimalisasi Peran Pendidikan dalam Pengembangan Ilmu dan Pembentukan Karaketr Bangsa (Jogjakarta: Ar-Ru Media, 2012), 126-127. 
pembelajaran diruangan kelas, tetapi dapat dilaksanakan diluar kelas juga, seperti membacakan sholawat nabi, belajar membaca al Qur'an dengan nada-nada yang indah, berbagai macam kegiatan ini dapat membantu terbentuknya karakter religius siswa.

\section{Konsep Pendidikan Humanis}

Pendidikan dalam arti luas merupakan proses pembelajaran yang berkaitan dengan upaya untuk mengembangkan seluruh kemampuan diri seseorang pada tiga sasaran aspek dalam menjalani kehidupan, yakni pandangan hidup, sikap hidup, dan keterampilan hidup. Pendidikan memiliki peran yang sangat penting dalam menyiapkan generasi muda untuk menjalankan kehidupan dan memenuhi tujuan hidupnya secara lebih efektif dan efisien. Pendidikan membimbing dan membentuk diri manusia menuju masa depan yang gemilang. ${ }^{17}$

Pengertian humanis yaitu usaha yang memusatkan sasarannya pada kemampuan manusia untuk digali dan ditingkatkan potensi yang dimilikinya. Dalam kerangka berfikir humanis, manusia diidentifikasi sebagai ciptaan tuhan yang dimiliki bakat-bakat dari lahir yang harus semaksimal mungkin. Bakat atau fitrah yang dimiliki manusia ini hanya bisa dibina dan ditempuh dengan upaya pelatihan dan pengajaran yang sistematis dan mengutamakan rasa kemanusiaan. Menurut Gagasan utama dari pemikiran Wijaya mengenai pendidikan humanistik, beliau berpendapat bahwa: "Menghormati harkat dan martabat manusia. Hal mendasar dalam pendidikan humanistik adalah keinginan untuk mewujudkan lingkungan belajar yang menjadikan peserta didik terbebas dari kompetisi yang hebat, kedisplinan yang tinggi, dan takut gagal”. Dapat disimpulkan Pendidikan humanis adalah: segala bentuk perkembangan kemampuan manusia harus dibina, dan tidak bermaksud untuk mengabaikan intelektual. Tujuan dari pendidikan humanis memusatkan perhatiannya untuk memajukan perkembangan potensi manusia dengan mengedepankan pendekatan yang berperikemanusiaan dalam dunia pendidikan.

Nilai-nilai dasar dan prinsip Pendidikan humanis adalah dasar pemikiran pembelajaran yang berguna untuk kemajuan potensi siswa yang meliputi, upaya pengajaran yang terfokus pada siswa, ${ }^{18}$ posisi guru yang memiliki jiwa tidak semenamena, pembelajaran yang mengedepankan persamaan hak dan kewajiban siswa, dan pembelajaran yang bersifat mampu memupuk saling bekerja sama. Gagasan tentang Pendidikan yang pendekatannya melalui humanis menghasilkan beberapa prinsip yang akan diuraikan dibawah ini:

1. Sasaran dan proses dalam Pendidikan bersumber dari siswa.

2. Siswa adalah anak yang memiliki potensi aktif.

3. Guru berperan untuk membimbing, menemani, dan memotivasi siswa agar mempunyai sifat kemandirian dalam menggali dan menenmukan ilmu pengetahuan ilmu pengetahuan.

${ }^{17}$ Zamroni, Pendidikan untuk Demokrasi: Tantangan Menuju Civil Society (Yogyakarta: Bigraf, 2001), 24.

18 Imam Bamadib, Dasar-dasar Kependidikan: Memahami Makna dan Perspektif Beberapa Teori Pendidikan (Jakarta: Ghalia Indonesia, 1996), 29. 
4. Sekolah merupakan ilustrasi kecil dari perwujudan atau gambaran terbentuknya lingkungan masyarakat luas yang akan dihadapi oleh siswa.

5. Rangkaian kegiatan pembelajaran harus menghasilkan solusi dalam memecahakan permasalahan, tidak semata-mata hanya menyampaikan materi pembelajaran.

6. Menciptakan suasana disekolah yang bersifat demokrasi dan saling bekerja sama, karena nantinya siswa akan hidup bermasyarakat beserta orang lain. ${ }^{19}$

Tujuan Pendidikan humanis adalah untuk mencapai tujuan dalam membangun peradaban yang berperikemanusiaan, terwujudnya dalam memperjuangkan pergaulan hidup yang lebih baik, dan peradaban yang mampu menghasilkan siswa yang mengabdikan diri untuk kebaikan seluruh umat manusia. ${ }^{20}$ Dengan demikian, manusia mempunyai hak yang sepatutnya dihormati dalam memperoleh proses pendidikan. Selama proses pendidikan juga harus selaslu menerapkan nilai kemanusiaan pada setiap siswa, karena siswa memiliki hak asasi yang harus dilayani sepenuhnya.

Pembentukan karakter religius melalui Pendidikan humanis adalah Upaya dalam menerapkan pendekatan yang bersifat humanis pada ranah pendidikan adalah bentuk tindakan nyata dari pendidikan dalam mengambil sikap sebagai usaha untuk menentukan prinsip atau pendirian dalam mencapai tujuan pendidikan. Hal tersebut diwujudkan dengan membimbing manusia melalui pendekatan yang bersifat humanis, sebab manusia memiliki berbagai potensi alamiah yang dapat dikembangkan lebih baik lagi. Oleh karena itu, nilai-nilai kemanusiaan akan ditanamkan untuk membentuk kepribadian yang berperikemanusiaan. Pendekatan yang bersifat humanisme dalam dunia pendidikan berfungsi untuk menggabungkan kemampuan manusia agar dapat berinteraksi dengan baik antar manusia, dan fokus menjalankan tugasnya sebagai pemimpin yang bertanggungjawab. Keseimbangan antara hak kebebasan penuh yang dimiliki manusia dan kewajibannya yang besar sebagai manusia merupakan peluang yang diberi oleh tuhan untuk memajukan dalam mengolah kemampuan yang dimilikinya. Oleh sebab itu, target dari teori humanisme adalah membina manusia agar cerdas dalam memberi solusi dalam menyelesaikan masalah, dan menjadikan manusia memiliki keimanan yang kuat pada tuhan. ${ }^{21}$

Faktor-faktor yang mempengaruhi dalam pembentukan karakter religius melalui pendidikan humanis yaitu: Dalam Mansur muchlis dijelaskan bahwa karakter merupakan kualitas moral dan mental seseorang yang pembentukannya dipengaruhi oleh faktor bawaan (fitrah, nuture) dan lingkungan (sosialisasi Pendidikan, nurture). Potensi karakter yang baik dimiliki manusia sebelum di lahirkan, tetapi potensi-potensi tersebut harus di bina melalui sosialisasi dan Pendidikan sejak usia dini.

1. Implementasi pendidikan humanis dalam membentuk karakter religius di SMK NU 2 Kedungpring Lamongan Tahun Pelajaran 2019/2020.

Berdasarkan data yang diperoleh bentuk implementasi di laksanakan dengan berbagai kegiatan, adapun kegiatan tersebut adalah:

\footnotetext{
${ }^{19}$ Mahmud Arif, Fisafat Pendidikan (Yogyakarta: Gama Media, 2007), 148-153.

${ }^{20}$ Muhammad A. R. Pendidikan di Alaf Baru: Rekonstruksi atas Moralitas Pendidikan (Yogyakarta: Prismashopie, 2003), 5.

${ }^{21}$ Abdurrahman Mas'ud, Menggagas Format Pendidikan Nondikotomik: Humanisme Religius Sebagai Paradigma Pendidikan Islam (Yogyakarta: Gama Media, 2002), 135.
} 
a. Bersalaman di pagi hari dengan para guru

Pertemuan setiap pagi hari disekolah diawali dengan berjabat tangan. Kebiasaan ini sudah dilakukan sejak lama oleh warga sekolah. oleh sebab itu, praktek berjabat tangan adalah bentuk penerapan humanisasi yang ada disekolah yang berfungsi sebagai rasa hormat siswa kepada gurunya, dan guru juga senantiasa memberikan rasa kasih sayang kepada siswanya. Gabungan keduanya menjadi landasan bagi siswa. Sehingga, siswa dibentuk karakter religiusnya dibangun dengan berdasarkan ajaran agama islam melalui Pendidikan humanism disekolah.

b. Berdo'a bersama yakni dengan pembacaan rutin surat yasin dan tahlil setiap hari jum'at pagi

Doa' Bersama di panjatkan dengan dipimpin guru agama, do'a sebagai usaha siswa setelah berusaha belajar dengan baik. Siswa diajarkan untuk selalu berdo'a, agar tidak hanya mengandalkan akal namun juga spiritualnya. Oleh sebab itu, pendidikan humanis tidak hanya memperhatikan aspek intelektual yang dimiliki para siswa yang harus diasah kecerdasannya, namun Pendidikan humanis juga menyeimbangkan siswa dengan mengolah kecerdasan spiritualnya, serta membentuk siswa memiliki kekuatan pada lahir dan batinnya.

c. Pembiasaan sholat dhuhur bersama-sama

Dilihat dari jenis kegiatannya, tanggung jawab kegiatan sholat menjadi ssepenuhnya milik guru agama. namun selain guru agama juga berpartisipasi dalam menjaga ketertiban siswa menjalankan sholat. Siswa yang rajin ibadah pun juga memberi semangat pada siswa yang malas dan berat diajak menjalankan sholat. Oleh sebab itu, hubungan kerjasama antara guru dan murid telah menciptakann susasana humanis yang membantu untuk mewujudkan dalam membina karakter religius siswa.

d. Sedekah sebagai bentuk peduli sosial

Lingkungan SMK NU 2 Kedungpring Lamongan terdapat kegiatan bersedekah yang dilakukan tiap kelas. Tiap kelas sedekahnya dapat disalurkan pada ketua kelas nya masing - masing. Kegiatan ini telah disetujui oleh pihak wali murid, sehingga tidak terjadi kesalah pahaman terkait kegiatan tersebut. Dana yang dikeluarkan untuk bersedekah tidak di tentukan nominalnya pihak sekolah, sebab hanya keikhlasan dari masing-masing siswa yang diminta. Dana yang dihasilkan dari sedekah para siswa, digunakan untuk kepentingan social jika terdapat warga sekolah mengalami musibah seperti contoh: ketika ada siswa yang sedang opname, kebakaran, orang tua siswa yang meninggal dll. Kepedulian sosial mengajarkan siswa untuk memiliki rasa kemanusiaan dan rasa kepekaan terhadap lingkungan yang mengalami musibah, sehingga siswa dibentuk yang awalnya hanya merasa terharu dan berduka, tingkat kepeduliannya semakin bertambah dengan melibatkan dirinya melalui tindakan nyata.

e. Memperingati hari kelahiran baginda Nabi Muhammad Saw

Pelaksanaan acara dalam memperingati hari kelahiran baginda nabi Muhammad dilaksankan di sekolah SMK NU 2 Kedungpring sebagai wujud 
besarnya rasa cinta warga sekolahnya kepada nabi Muhammad, disamping itu acara tersebut diadakan untuk mendidik siswa agar memiliki rasa cintanya kepada nabi Muhammad. Upaya ini sangat penting untuk dijadikan kegiatan wajib setiap tahun, dikarenakan kepribadian nabi Muhammad adalah tokoh yang layak dijadikan figur oleh siswa. Kegiatan ini dihadiri oleh semua guru bergabung dengan siswa yang di dekatnya dalam membaca sholawat yang benar. Oleh karena itu, kedekatan yang terjalin antara guru dengan siswa sebagai bentuk proses humanisasi yang dapat dimanfaatkan kedekatannya dengan melatih kemampuan siswa dalam membaca sholawat, serta membina emosionalsiswa sejak dini agar tertanam rasa cinta kepada nabi Muhammad.

2. Faktor yang mempengaruhi pembentukan religius siswa melalui Pendidikan humanis Dalam pembentukan karakter tidak dapat terbentuk begitu saja, adapun faktor yang mempengaruhi sebagai berikut:

a. Faktor pendukung

Adanya kemauan siswa untuk berfikir maju, berfikir maju memiliki arti berfikir mengikuti perkembangan zaman yang selalu berubah-ubah. Pada zaman modern seperti ini, jika peserta didik tidak bisa mengikuti perkembangan zaman yang semakin canggih mereka akan tertinggal jauh akan perabadannya. Selain itu faktor pendukung diterapkannya Pendidikan humanisme adalah adanya perhatian dan dukungan dari komite dari sekolah, dengan adanya dukungan dari pihak komite sekolah menjadi nilai tambah tersendiri.

b. Faktor penghambat

Adapun yang menjadi faktor penghambat dalam pembentukan karakter religius melalui pendidikan humanis adalah munculnya faktor internal dan eksternal diantaranya adalah kurangnya guru pendidikan agama, guru merupakan elemen terpenting dalam pembentukan karakter religius melalui pendidikan humanis guru harus penuh mengajar disatu lembaga pendidikan. Selain kurangnya jumlah guru faktor penghambat lainnya adalah kurangnya pemahaman guru menganai pendidikan humanis hanya sebatas mengerti saja belum memahami secara keseluruhan. Faktor penghambat lainnya adalah mengenai sarana dan prasarana karena dengan adanya fasilitas yang memadai menjadi suatu hal yang mendukung dalam kegiatan belajar mengajar.

\section{Kesimpulan}

Berdasarkan diskusi dan pembahasan yang dipaparkan maka dapat disimpulkan: Implementasi Pendidikan humanis dalam membentuk karakter religius di SMK NU 2 Kedungpring dapat terwujud melalui pelaksanaan pembiasaan berinteraksi antara guru dengan peserta didik dan peserta didik dengan sesamanya dengan mengedepankan nilai-nilai kemanusiaan dan keagamaan. Selain itu, faktor yang mempengaruhi pembentukan karakter religius melalui pendidikan humanis meliputi: kemauan siswa berfikir maju yakni mengikuti perkembangan zaman, kemudian juga adanya dukungan dari komite. Dan adapun faktor penghambat nya adalah kurangnya jumlah guru agama dan menjadi berhasil atau tidaknya dalam mengimplementasikan Pendidikan humanis 
dalam bentuk karakater religius, kemudian juga kurangnya sarana dan prasarana yang menunjang keberhasilan dan kenyamanan dalam proses pembelajaran.

\section{Daftar Rujukan}

Majid, Abdul dan Dian Andayani, Pedidikan Karakter Prespektif islam, Bandung: PT Rosdakarya, 2013.

Lickona, Thomas, Educating For Character: How Our School Can Teach Respect And Responsibility New York: Bantam Books, 1991.

Lexy J. Moleong, Metode Penelitian Kualitatif , Bandung: PT. Remaja Rosda Karya, 2006.

Bungin, Bungin, Penelitian Kualitatif, Jakarta: Prenada Media Group, 2007.

Matthew B. Miles and A. Michele Hubberman, Qualitative Data Analysis: An Expanded Sourcebook London: SAGE Peblication, 1994.

Lincoln and Guba, Effective Evaluation, Improving The Usefullness Of Evaluation Result Hrough Responsive And Naturalistic Approaches, San Fransisco: California, 1981.

Hasanah, Aan Pendidikan Karakter Prespektif Islam, Bandung: Insan Komunikasi,2012.

Mohammad Mustari, Nilai Karakter: Refleksi untuk Pendidikan, Jakarta: PT Raja Grafindo Persada, 2014.

Fathurrohman, Muhammad, Budaya Religius Dalam Peningkatan Mutu Pendidikan: "Tujuan Teoritik dan Praktik Kontekstualisasi di Sekolah", Yogyakarta: Kalimedia, 2015.

Ancok, Djamaludin dan Fuad Nasori Suroso, Psikologi Islam, Yogyakarta: Pustaka Pelajar, 2005.

Naim, Ngainun, Character Building: Optimalisasi Peran Pendidikan dalam Pengembangan Ilmu dan Pembentukan Karaketr Bangsa, Jogjakarta: Ar-Ru Media, 2012.

Zamroni, Pendidikan untuk Demokrasi: Tantangan Menuju Civil Society, Yogyakarta: Bigraf, 2001.

Bamadib, Imam, Dasar-dasar Kependidikan: "Memahami Makna dan Perspektif Beberapa Teori Pendidikan”, Jakarta: Ghalia Indonesia, 1996.

Arif, Mahmud Fisafat Pendidikan, Yogyakarta: Gama Media, 2007.

R. Muhammad A. Pendidikan di Alaf Baru: Rekonstruksi atas Moralitas Pendidikan Yogyakarta: Prismashopie, 2003.

Mas'ud, Abdurrahman Menggagas Format Pendidikan Nondikotomik: Humanisme Religius Sebagai Paradigma Pendidikan Islam Yogyakarta: Gama Media, 2002. 